\section{More cash for British science}

The UK Advisory Board for the Research Councils (ABRC) is considering how to divide the second windfall to have landed in its lap this month amongst the five research councils. In reply to a question in the House of Commons late last week Shirley Williams, Secretary of State for Education and Science, announced an extra $£ 4$ million for the science budget which is to be spent on "new capital work" in 1978-79. It is in addition to the $£ 4$ million allocated to the research councils in the mini budget at the beginning of the month.

The new $£ 4$ million is to come out of the $£ 400$ million allocated to the construction industry in the mini budget. It is strictly for building and, because of its small size, is more likely to be used for improving or extending existing facilities than starting up new ones.
Professor Geoffrey Allen, Chairman of the Science Research Council, which is almost certain to get the lion's share, would like to see the money going towards finishing construction already begun and extending central user facilities. $\mathrm{He}$ feels that this might be an opportunity to complete the nuclear structure facility at the Daresbury Laboratory and extend facilities for the synchroton source there. The laser facility and spallation neutron source at the Rutherford Laboratory might also come in for a share of the cash.

Another priority in the SRC is likely to be helping universities provide facilities for marine technology and polymer engineering. These are research areas considered to be of national importance and currently receiving special treatment from the SRC. The only new project which might be considered is an electron beam lithography unit for microelectronics which could be set up in existing buildings at the Rutherford.

The cost of implementing these projects alone could come to $£ 3$ million. When the cost of the bids for support from all the research councils is added up, it will undoubtedly be much more than $£ 4$ million, so the ABRC is in for a difficult task. Nevertheless, it hopes to have made the necessary decisions by the end of next week or at the latest by its next formal meeting which is set for 9 December. A decision on the earlier $£ 4$ million, however, is unlikely to be made public before the end of the year although it has been made and is awaiting Mrs Williams' approval. It will probably simply be added on to the total science vote for 1978-79 which will be announced sometime in the new year.

Judy Redfearn

\title{
Leading Soviet dissidents in London
}

DURING the last month, three leading figures from the Soviet dissidence and human rights movement have visited London. According to the most recent arrival, Dr Khronid Lyubarskii, an astrophysicist, their presence in the West reflects a determined effort on the part of the Soviet authorities to overthrow all opposition, neutralising the leaders by removing them from the scene. Neither Dr Lyubarskii nor Dr Valentin Turchin, the cyberneticist, who were expelled together on 14 October, had any real desire to leave the Soviet Union. They had applied for emigration only when the authorities had made it clear that they must choose between foreign exile or a protracted stay in a labour camp. The third visitor, Professor Mark Azbel, a theoretical physicist, had indeed had a genuine wish to leave the Soviet Union, having applied several years ago for a visa for Israel. After several years as a refusnik, Azbel finally received his visa last June.

It is no coincidence that all three are scientists. The dissident movement has a strong bias towards the scientific professions, since, in Dr Lyubarskii's words, "a scientist works in information-it is therefore natural that he begins to think about the society around him. It is the critical mind of scientists that leads them to think of human rights".

Their record of service to the human rights movement is impressive. As early as 1970 Turchin, together with Roy Medvedev, signed the second Sakharov letter. In 1972, Lyubarskii was sentenced to five years in a strictregime Labour camp for his human rights activities, and while there organised the observance of an annual Political Prisoners' Day (30 October), to be marked with protests and hunger strikes. For this further transgression, Lyubarskii was transferred to the VIadimir prision for the duration of his term. Both Turchin and Lyubarskii became members of the illicit Moscow group of Amnesty International, and were associated with the Helsinki monitoring group.

On the arrest of Aleksandr Ginsburg last April, Lyubarskii took over the administration of the Solzhenitsyn fund for aid to political prisoners. Unlike many Jewish activists, Dr Azbel feels it better to keep the Jewish emigration movement separate from the dissident movement for reform and human rights. This is not a distinction, however, which the Soviet authorities accept-application for emigration is an antisocial act, just as much as signing a petition of protest, and is punished in the same way by dismissal from one's job, with no possibility of continuing one's professional career.

Dr Luybarskii gave an interesting estimate of the numbers of scientists penalised for their activities :

involuntary foreign exile a few arrests

expelled from jobs

tens routine restrictions after thousands signing protests etc (refusal of foreign passport, administrative restrictions).
It should be remembered that punitive dismissal is far more serious a penalty than loss of job. In the Soviet Union no academic article can appear without a certificate from the academic institution where the author is employed. No 'freelance' submissions are permitted. "If Einstein or Faraday had lived in the Soviet Union, they could never have published their theories" stressed Azbel.

How well a scientist can survive professionally under such conditions seems to depend very largely on his particular field. In spite of several years without employment or professional facilities both Turchin and Azbel have found themselves able to continue their professional careers in the USA and Israel respectively. For Dr Lyubarskii, however, the outlook is bleak. His special field, the physics of planets, meteors and meteorites has moved forwards at such a pace that he feels doubtful whether he will ever catch up after almost six years with no access to journals.

Whatever their new professional commitments, all three are firmly committed to campaign for fellowscientists still suffering constraint and imprisonment, and, indeed, they came to England for this purpose. They will campaign for physicist Yurii Orlovnow in prison; biologist Sergei Kovalev -in a labour camp; mathematician Viktor Brailovskii, Azbel's successor as leader of the Sunday seminar, who is threatened with a treason charge; and the young mathematician Anatolii Shcharanskii whose trial on treason charges now appears to be imminent.

Vera Rich 